\title{
RENOVATION OF LAO HOUSES IN SUBURBAN VILLAGES OF VIENTIANE, LAO PDR \\ ラオス・ヴィエンチャンの周辺村落における Lao house の住宅改善に関する考察
}

\author{
Saysavanh PHONGSAVANH* , Hirokazu ABE ${ }^{* *}$ and Katsuyuki YOSHIDA*** \\ ポンサワン サイサワン，阿部浩 和，吉田勝行
}

\begin{abstract}
This paper aims to identify the conditions and perception for renovation of Lao houses in suburban areas in Vientiane, to support the expectation of the future lifestyle of Lao house in the urbanizing of Vientiane, Lao PDR. The field survey of 32 houses and questionnaires had been undertaken in July-August 2007 in two suburban villages (Ban-Phosi, and Ban-Thongmang) of Vientiane, The main findings were; 1) An increasing number of renovations of Lao houses were found from 1995. This seems to be connected with the beginning of the Vientiane Integrated Urban Development Program (VIUDP) in 1994; 2) In Ban-Phosi, as an older village, number of renovation house is larger than in Ban-Thongmang. Ban-Thongmang, a newer village, where more inhabitants perform agricultural production was found more renovation of roof and extension of warehouse; 3) First step of renovation is mainly sanitary equipments, second step is mainly communicational or relaxing room extended, and the third step is mainly changing material; 4) Extensions were classified into six types. The side extended rooms in ground floor could be mainly used as shop. And the enclosed rooms on the underneath could be mainly used as living area for the extended family; 5) There are few inhabitants residing in the house that build a wall on the ground floor planed to "destroy and build a modern house". These types seem to be responded to the need of recent lifestyle; 6) Most of the younger families (under 30 years old) want to destroy and build a modern house. The middle aged families (30-40 years old), reported proportions of "destroy and build modern house" and "some renovations" similarly at approximately 40\%. Among the older families (above 40 years old), the response rate of "keep the same style" reached $50 \%$.
\end{abstract}

Keywords: Renovation process, Lao houses, Vientiane suburbs, Ban-Phosi and Ban-Thongmang リノベーション過程，ラオ八ウス，ヴィエンチャン郊外 ポウシ村、トマン村

\section{INTRODUCTION}

\subsection{Background}

Vientiane has experienced remarkable growth, and multiple modern housing developments have appeared throughout the city and suburbs*1). In the mid-1990s, however, the cultural heritage sites of Vientiane and other regions in the Lao PDR suffered extensive damage (LOGAN, et al. 2003), due primarily to the increased number of foreign tourists and foreign investment. In addition, young people in rural and remote areas gradually migrated to the cities, thus increasing the urban population. These social trends created an immediate need for more residential development in Vientiane.

However, importation of new industrial materials ${ }^{* 2)}$, and the changing perceptions of modern living, affected the lifestyle of residents. Traditional Lao houses in urban area were destroyed and replaced by modern buildings, leaving Lao houses in the urban area at the highest risk of disappearing (SAYARATH, 2003). In the suburbs, areas of middle density of population, however, more Lao houses were affected by the process of urbanization. In these areas, construction materials for Lao houses began to change, while some rooms were extended to create more living spaces (CHAZEE, 1999).

Moreover, the renovation of traditional Lao houses is another option to protect this form from being destroyed and replaced by modern-style houses, The study of renovation of traditional Lao houses will be vital for preserving this form and preventing its disappearance in the future.

\footnotetext{
* Ph. D. Candidate, Graduate School of Eng., Osaka University, M. Eng.

** Prof., Cyber Media Center, Osaka University, Dr. Eng.

*** Prof. Emeritus, Osaka University, Dr. Eng.
}

大阪大学大学院工学研究科 博士後期課程 $\cdot$ 工修

大阪大学サイバーメディアセンター 教授・工博

大阪大学 名誉教授・工博 


\subsection{Aim of this research}

The aim of this paper is to identify the conditions and processes of renovation, and to clarify the motivations for renovating Lao houses. Thus, this study examines the followings aspects: 1) processes of renovation of individual houses; 2) household size and occupation, and 3) perception and future prospects for renovation.

\subsection{Definition of "Lao house"}

Several researchers have proposed various definitions of the "Lao house" *3). LEBAR and SUDDARD (1967) suggested that "Lao house" with its characteristic of wooden house built on stilts with gable roof has existence since $14^{\text {th }}$ century*4). CLEMENT (1990) refer to "Lao houses" as houses on stilts, where peoples were playing the Khene ${ }^{* 5}$ ) and eating sticky rice with Padeck $^{* 6)}$ with the main characteristics of Lao people. CONNERS (1996) notes that traditional "Lao houses" are constructed of bamboo and wood and rest on wooden piles with roof of palm and grass thatch. CHAZEE (1999) suggested that since 1985, tendency to use the ground floor by building brick walls between the stilts to create living area, toilet, kitchen, and so on. KOMOTO, et al. (2004) uses this term to indicate stilt houses, the majority housing style of Lao people.

In this paper, we use this term "Lao house" to designate conventional Laotian traditional wooden houses built on high stilts and with verandas. Such houses are protected with gable roofs with stilts to protect the house from mud, floods, and wild animals.

\subsection{Review of the literature}

A few studies have been concerned with the characteristics, transformation or renovation of houses in Laos.

KOMOTO, et al. (2004) examined the modal characteristics of rural houses and their transition focusing on mountainous area of Lao. CLEMENT (1990) examined the traditional house and lifestyle of inhabitants in Vientiane and Luang Prabang. However, these papers focus on the traditional Lao house in rural areas or preservation districts.

MIYASAWA, et al. (2004), on the other hand, examined the principles of dwelling and village composition in Tariang group, focusing on the living style of hill tribes' settlements in Lao PDR. FUKUYAMA, et al. (2005) examined the residential space and the way of life of Kado group focusing on the Longhouse of Tanggo village, Pin-B village in the south of Laos. HIRATA, et al. (2006) examined the spatial property and transformation of Aka group's village in the north of Laos. And TOSHIMA, et al. (2007) examined the cluster of residences in the temporary dwelling place of Hmong group in the surroundings of Vientiane, Lao PDR. Each of these papers focused on the houses of ethnic minority group*7) in Laos.
DENPAIBOON, et al. (2000) examined the typology and lifestyles involving raft houses in riverine settlements in Thailand. And CHIRANTHANUT and FUNO (2008) clarified the transformation of Kaloeng houses in a northeastern province of Thailand. These studies, however, addressed the subject in Thailand.

Therefore, there are few significant studies concerning the renovation of Lao houses. Our previous study*8) (2009) focused on inhabitants' consciousness concerning detached houses in the city and suburbs of Vientiane. The present paper is designed to identify the key aspects and processes in the renovation of Lao houses in suburban areas of Vientiane. Thus, it aims to offer an approach and focus not explored in previous studies.

\section{METHOD}

This study is based on a field survey, which included methods such as a questionnaire, sketching of housing layouts, measuring physical dimensions, photographic documentation and personal interviews. The questionnaire was concerned with the conditions of the houses and households focusing on the following variables: 1) general information on the household, 2) inhabitants' ages and occupations, 3) period and contents of renovation, and 4) perception and future prospects for renovation. These field surveys were undertaken from July to August 2007 in suburban areas of Vientiane, in cooperation with the National University of Laos. The study proceeded by first performing observations of the entire two villages, respectively and discussions with the leaders of the villages for selecting the houses to be used as samples for investigation. The questionnaire was then provided to members of each selected household, taking 25 to 45 minutes to complete. Sketching and measuring the physical dimensions of each sample house took from 1 to 2 hours.

\subsection{Area of Research}

Vientiane is the capital of the Lao PDR, and comprises nine districts*9) as shown in fig.1. For purposes of this study we divided Vientiane into three zones based on distance from the center as follows:

A Zone (10km from the center): This zone is characterized by a high population density and the intense presence of human features compared with surrounding areas. This is the center of Vientiane, and includes mainly four districts (Chanthabouli, Sisattanak, Sikhottabong, and Xaysettha).

B Zone $\left(10 \mathrm{~km}^{-} 20 \mathrm{~km}\right.$ from the center): This zone including the mainly two districts of Hatxayfong, and Saythani, is considered the suburbs of Vientiane and a residential area, with lower population density than the inner city neighborhoods.

C Zone $\left(20 \mathrm{~km}^{-} 80 \mathrm{~km}\right.$ from the center): This zone is a large and isolated area with low population density. It includes mainly three districts (Naxaythong, Paknguem, and Sangthong). As 
some villages in these districts are difficult to access by road, residents' lifestyle and housing style have not changed as much as those in the urban area.

This study of renovation of Lao houses focuses on the B Zone as it is between the more highly urbanized and rural areas. This zone may possibly be developed in the near future in the process of urbanization, when more Lao houses and renovation can be expected. Fig. 2 shows the population size and density of each district. Based on this data, we selected two districts (Saitani and Hassayfong) in the middle level of population density.

This study selected a representative village in each district of middle-level population density, these being two villages of Ban-Phosi (Hatxayfong district) and Ban-Thongmang (Saythani district).

Both villages have been affected by the impact of urbanization, with modern facilities being introduced. However, their original appearances still remain.

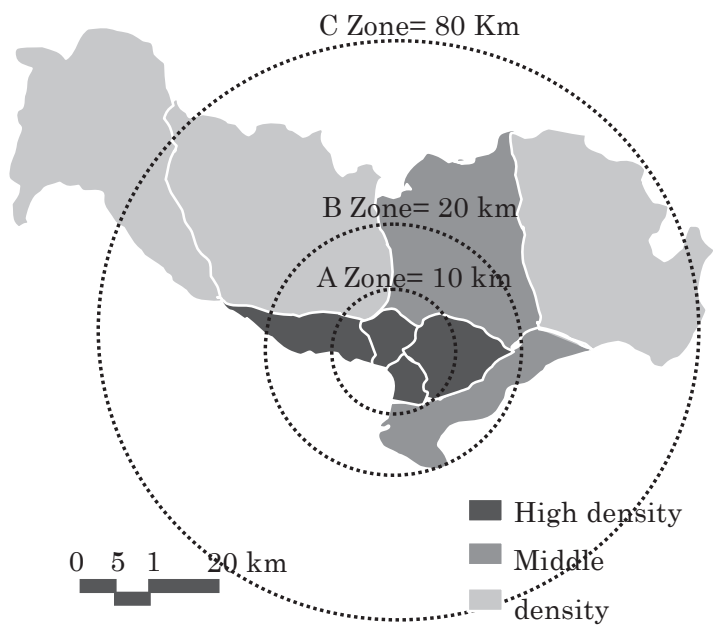

Fig. 1 Zones of Vientiane based on distance from center.

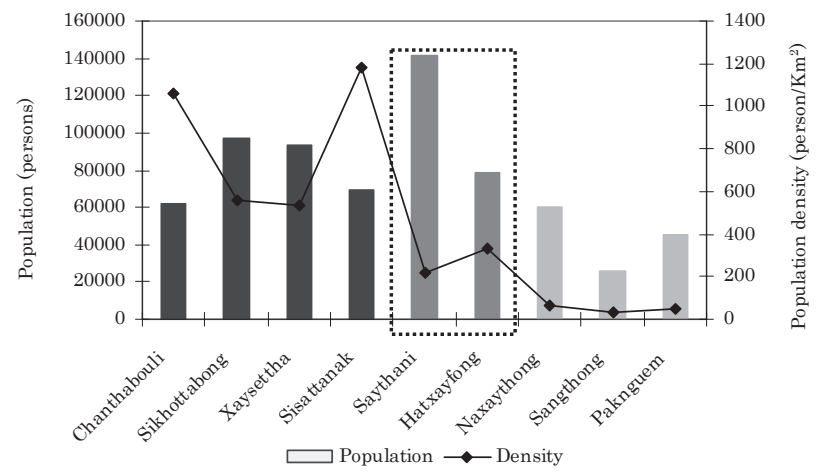

Fig. 2 Population size and density of districts in Vientiane.

Fig. 3 and 4 show the layout of each village. Ban-Phosi is located at the center of the district and on the main road from Vientiane to the Ban-Hom area (the famous fruit and vegetable farm area of Vientiane), and is surrounded by paddy fields, and vegetable and fruit farms. In this village there is one temple and one primary school. Ban-Phosi has been in existence since a few years after the establishment of "Vientiane" in 1560. In 2005, there were 175 households with a population of 827 in the village (21ha). The main occupation of the population, amounting to $31 \%$ is agriculture. Ban-Thongmang is a new village formed by the settlement of people who migrated from Xiengkuang province to this area in 1920 with the first of 22 households. By 2005 that had expanded into 434 households with a population of 2569 in the village (70ha). The main occupation of population with $55 \%$ is agriculture.

During the field survey, we consulted with the head of each village concerning selection of sample houses Lao houses or renovated Lao houses for this research. Due to the system of administration in Laos, it is difficult to conduct field surveys without the cooperation of local authorities. Through this process, 32 households were selected from the two villages.

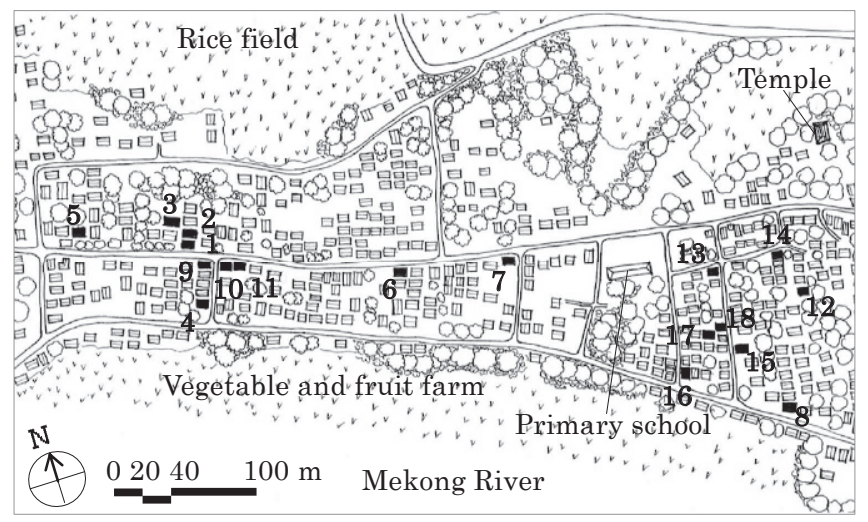

Fig. 3 Layout of Ban-Phosi and No. of houses surveyed.

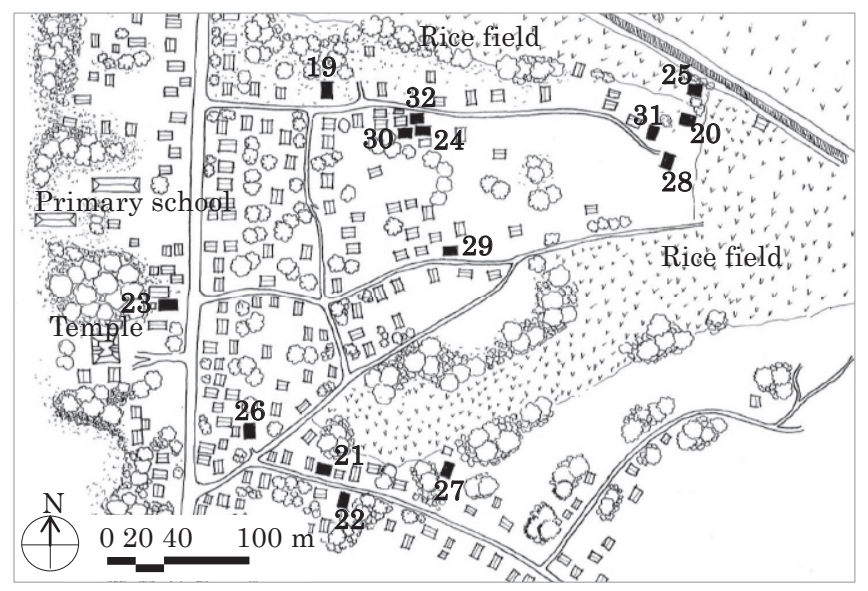

Fig. 4 Layout of Ban-Thongmang and No. of houses surveyed.

\section{RESULTS AND DISCUSSION}

\subsection{Results of the field survey}

First of all, we intended to show the detail of samples in our works to understand more concretely issues related to our field survey. These two samples were selected from our first investigated houses in each village as follows: 


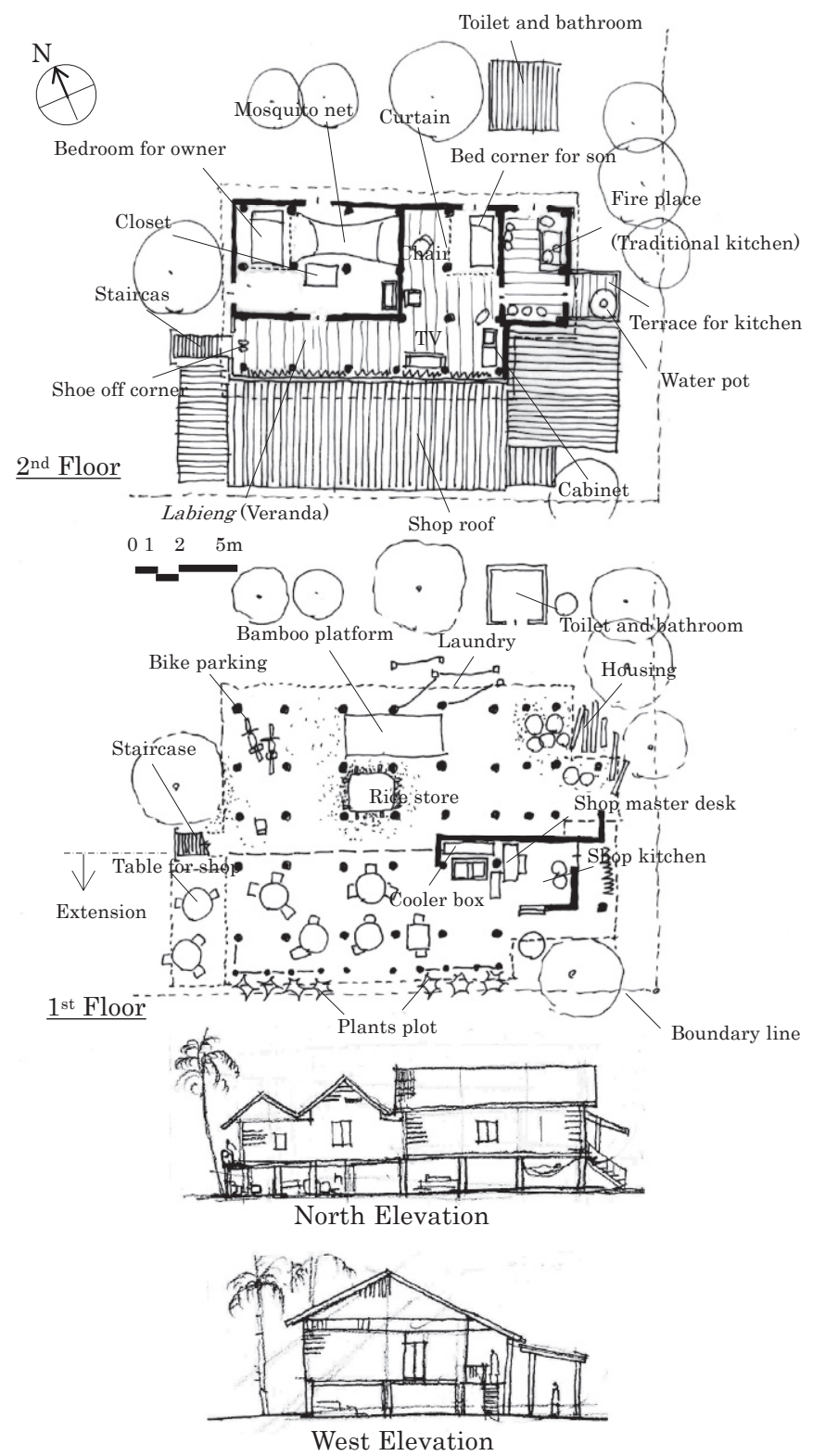

Fig. 5 Sketch of investigated house number 1.

*Source: These sketches are the original sketch from field surveyed.

House number 1: This house is located in Ban-Phosi and belongs to a family of five members. The main occupation of this family is agricultural production mainly paddy field farming. Constructed in 1955, the house is located along the main road of the village. It is a stilt house with open ground floor. The structure, walls, and floor are built of wood, with a roof of zinc. There is one main bedroom divided by curtains into two parts, the first part allocated to the parents and the other part to the grandmother and a young daughter. Outside of the bedroom, there is a space next to the kitchen and Labieng (verandas) where the bed for a son is located. There is no specific wall for the son's bed, but it is surrounded by a curtain. On the ground floor there is a bamboo platform, rice storage, a hammock, and a laundry place.

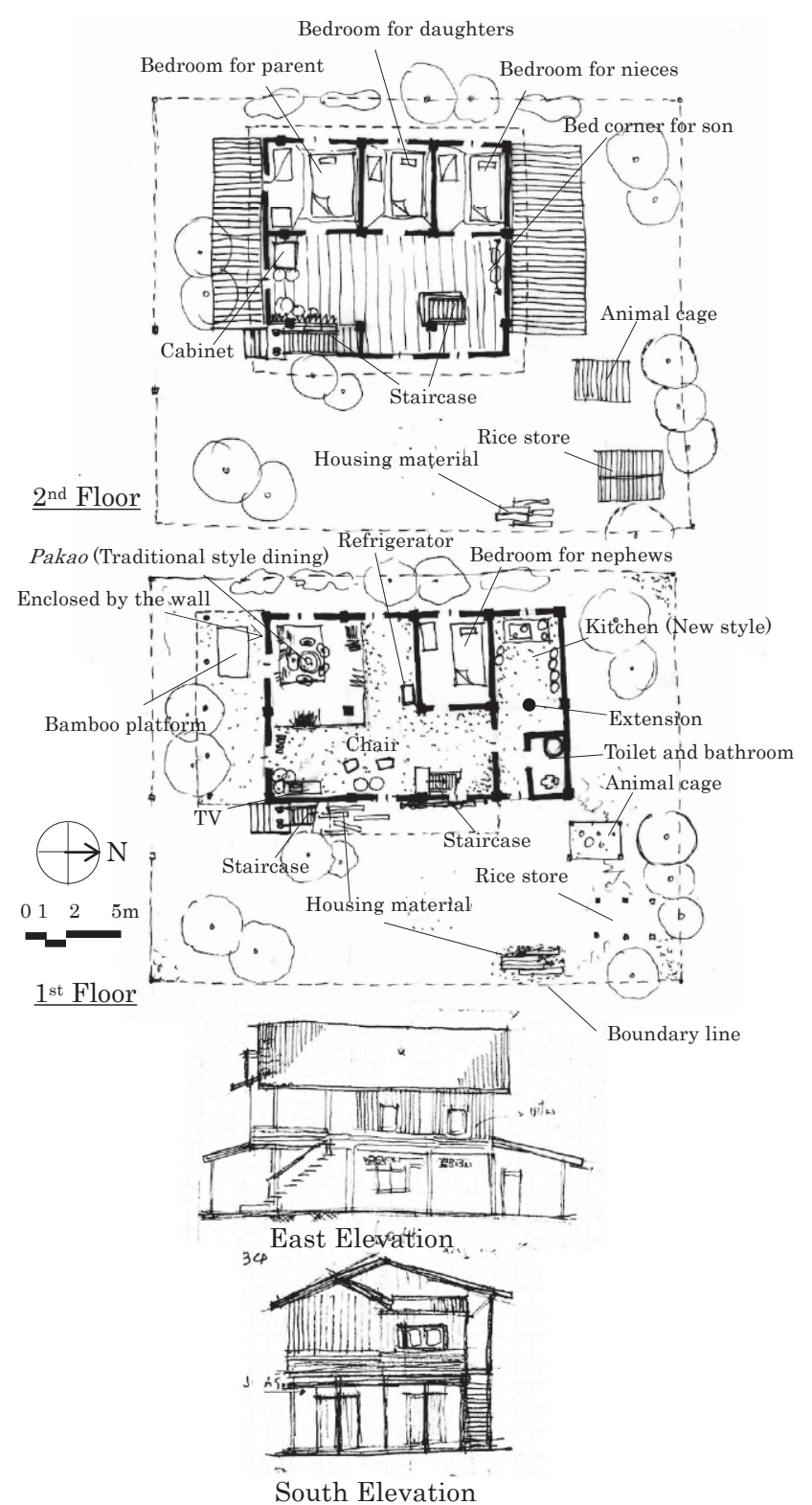

Fig. 6 Sketch of the investigated house number 19 .

*Source: These sketches are the original sketch from field surveyed.

In 2007, a renovation of the house was performed which included the construction of toilet, bathroom, and shop. The toilet and bathroom were in the same room that built detached to the back side of the house. The shop was built connected from the roof of the Labieng of the main house to the ground level on the house's side. The shop was built with a zinc roof and cement floor, as show in fig. 5. The total floor area before renovation was $61 \mathrm{~m}^{2}$, extending to $100 \mathrm{~m}^{2}$ after renovation.

According to the results of the questionnaire and interview, the owner of the house still expressed dissatisfaction with the room's size after the renovation. Feeling the house was too old, the owner would like to destroy it and replace it with a modern style house in the future. 
Table. 1 Floor plans, renovations and household composition of the investigated houses.

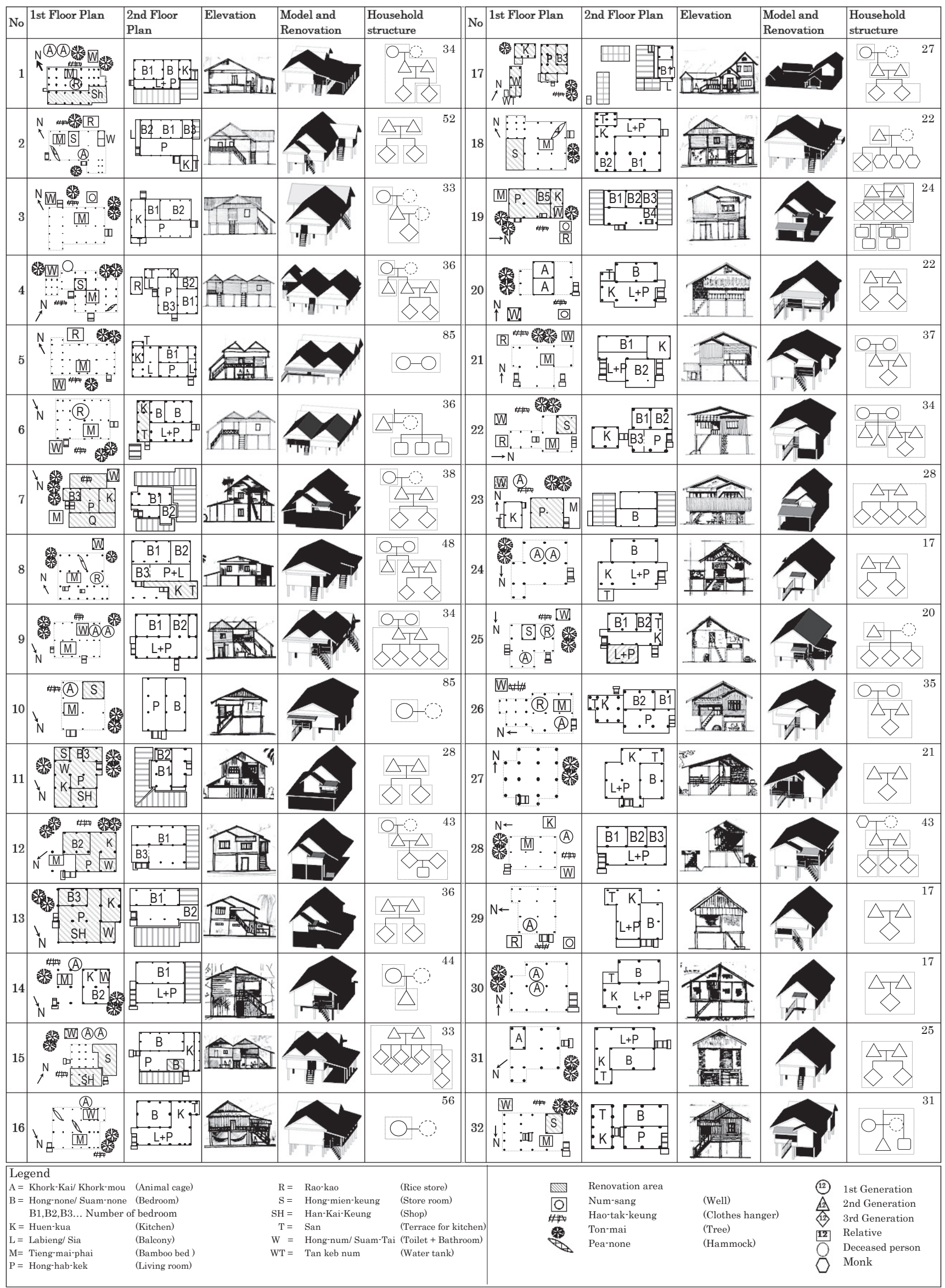

*Source: These sketches are the original sketch from the field surveyed, the 3DCG modeling are not included the detach building. 
House number 19: This house is located in Ban-Thongmang, and belongs to a family of ten members. The main occupation of this family is also agriculture mainly paddy farming. This house was constructed in 1980 along the main road of the village. It was previously a stilt house with an open the ground floor. The material of the structure, walls, and floor is wood, with a roof of terracotta. There are three bedrooms in this house. The first bedroom is for parents, the second is for two daughters and the third for two nieces. The son's bed is placed on the veranda on the upper floor outside of the bedroom. Three nephews are sleeping in the bedroom that resulted from renovation in the ground floor.

In 2006, renovation of the ground floor was performed. The ground floor was walled with bricks surrounding the stilt, and floored with cement. The renovated area consists of a large living room, a bedroom, kitchen, toilet, and bathroom, as shown in fig. 6 . The total floor area of the house before renovation was $84.8 \mathrm{~m}^{2}$ increasing to $192.8 \mathrm{~m}^{2}$ after renovation.

According to the investigation, after renovation, the owner of this house was still not satisfied with the size of the living room, but was satisfied with the other rooms. The owner of this house had no plans for more renovation of the house in future.

\subsection{Overview of the surveyed houses}

Table 1 illustrates data from 32 houses obtained from the field survey. The table presents sketches of ground and upper floor plans on the left side with renovation positions indicated by the dark shading for each plan, then the sketch of elevation, and the 3DCG modeling indicating the renovated positions with dark shading for each houses. In the far right columns, the composition of the household inhabiting each house is recorded, with the circle shape $(\bigcirc)$ representing the first generation (grandparents), the triangle shape $(\triangle)$ representing the second generation (parents), and the rhombus shape $(\diamond)$ representing the third generation (child), the square shape ( $\square$ ) representing the other relatives, and the hexagon shape $(\square)$ representing the member of household who being monk. The circle with continue line indicates the deceased member. The number on the top right is the average age of each household. Enclosures around multiple or individual family members indicate the groups that slept in the same room.

Table. 2 The household size (persons per household)

\begin{tabular}{|l|c|c|}
\hline Location & Average of samples & Average of the whole village* \\
\hline Ban-Phosi & 4.5 & 4.7 \\
\hline Ban-Thongmang & 4.6 & 5.9 \\
\hline
\end{tabular}

* (LNSC) Lao National Statistic Center, Vientiane Population Census 2005.

Table 2 shows the average number of household members in this study area. According to the samples in the survey, the average household size in Ban-Phosi is 4.5 (persons/household), and in Ban-Thongmang is $4.6(\mathrm{p} / \mathrm{h})$. However, the average of household size in the whole village of Ban-Phosi is $4.7(\mathrm{p} / \mathrm{h})$, while in the whole village of Ban-Thongmang is 5.9(p/h), (LNSC, 2005). The data shows that there is not much difference in household size among families in Ban-Phosi.

\subsection{Conditions and Processes of Renovation}

\subsubsection{History of surveyed Lao houses in the two villages}

Fig. 7 shows the history of each house in the field survey. There were 13 houses first built during 1955 to 1970 all in the old village of Ban-Phosi. A total of 7 houses were first built between 1975 to 1995 including 3 in Ban-Phosi and 4 in Ban-Thongmang. Another 12 houses, 2 in Ban-Phosi and 10 in Ban-Thongmang were established from 1995 to 2007. The houses of Ban-Phosi are older than those of the more recently established Ban-Thongmang.

As fig. 7 illustrates, many houses underwent renovation after being established for a few years. However, there were 6 extensions and 2 repairs performed from 1960 prior to 1995. But there were 27 extensions and 4 repairs performed from 1995 to 2007. Renovation of the houses significantly increased after 1995 This likely reflects Laos's history. From the establishment of the Lao PDR in 1975, the country was closed to the outside world for a decade, hampering private investment throughout the country until the open-door market-oriented reform policy was launched $1986^{*}{ }^{10)}$ and after that the major planning guideline of Vientiane Integrated Urban Development Program was produced in $1994 * 11$.

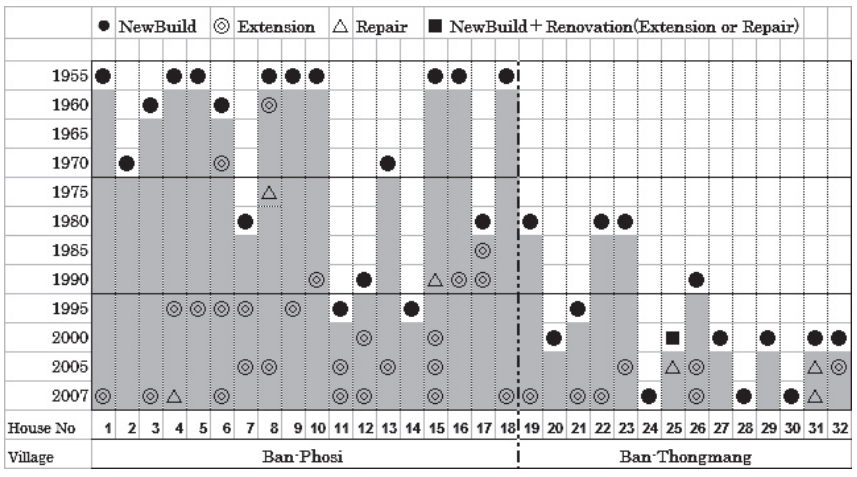

Fig. 7 History of construction and renovation

\subsubsection{Contents and floor area of renovation}

Fig. 8 shows the contents of extension and repair in the two villages. In Ban-Phosi, the higher rate of contents for renovation found was the extension of toilet, bathroom, and kitchen. In Ban-Thongmang, the higher rate of contents for renovation found was extension of toilet, repairing the roof, and extension of the warehouse. However, while the extension of the shop was found in Ban-Phosi, this was not found in Ban-Thongmang. And the extension of warehouse was found more in Ban-Thongmang. This may be related to the fact that inhabitants of 
Ban-Thongmang perform more agricultural production, as show in Table 3.

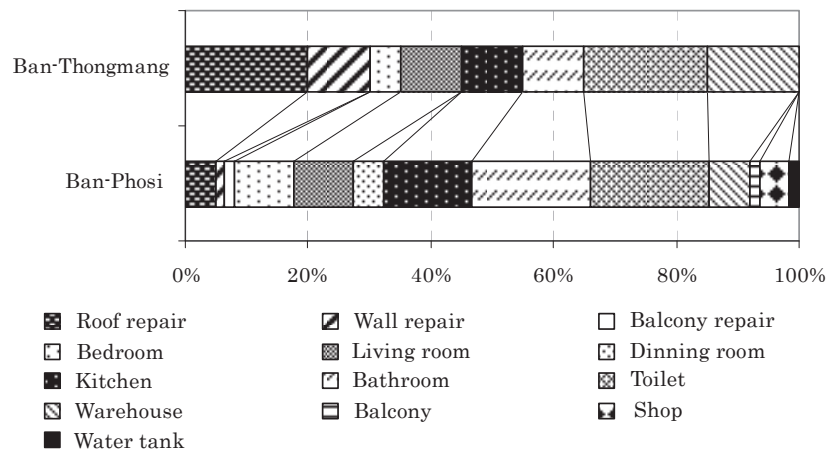

Fig. 8 Content of extension and repair

Table. 3 Occupation of inhabitant

\begin{tabular}{|l|c|c|}
\hline Location & Agriculture & Other \\
\hline All Vientiane* & $35 \%$ & $65 \%$ \\
\hline Ban-Phosi & $31 \%$ & $69 \%$ \\
\hline Ban-Thongmang & $55 \%$ & $45 \%$ \\
\hline
\end{tabular}

Fig. 9 shows the floor area before and after renovation in each house. The average floor area of houses in Ban-Phosi before renovation is $95.4 \mathrm{~m}^{2}$ and after renovation is $139.4 \mathrm{~m}^{2}$, while the average floor area of houses in Ban-Thongmang before renovation is $55 \mathrm{~m}^{2}$ and after renovation is $71 \mathrm{~m}^{2}$. However, the average floor area after renovation of houses in Ban-Thongmang is smaller than that of Ban-Phosi as shown in Table 4.

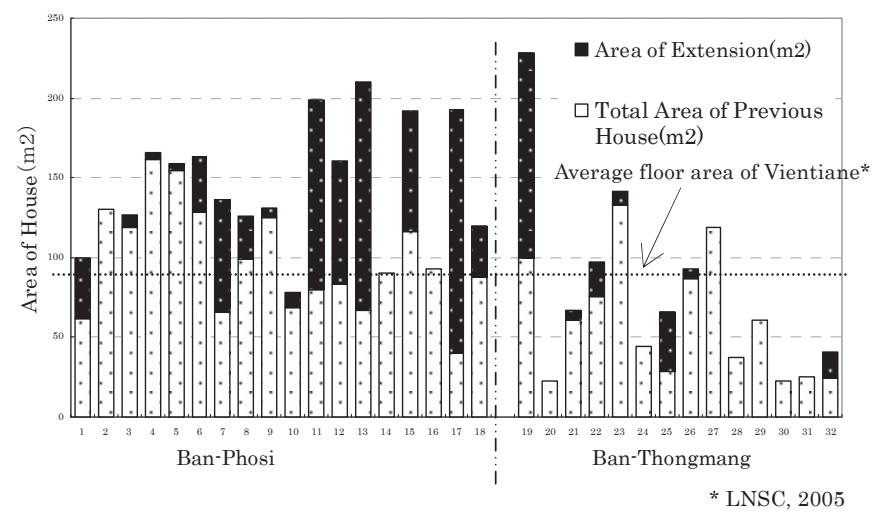

Fig. 9 The area of house before and after renovation

Table. 4 Average floor area $\left(\mathrm{m}^{2}\right)$

\begin{tabular}{|l|c|c|}
\hline Location & Before Renovation & After Renovation \\
\hline Ban-Phosi & 95.4 & 139.4 \\
\hline Ban-Thongmang & 55 & 71 \\
\hline
\end{tabular}

\subsubsection{Step of Renovation}

Fig. 10 shows the contents in several steps in the process of renovation ( $1^{\text {st }}, 2^{\text {nd }}$, and $3^{\text {rd }}$ periods). The most common contents of renovation found in first step are renovation of toilet, bathroom, and then kitchen. While in the second step the content of renovation was bedroom, and living room. In the third step, the content of renovation was repairing of roof. This result suggests that the first step of renovation for inhabitants is mainly sanitary equipment, and the second step of renovation is mainly communicational or relaxing room extended, and the third step of renovation is mainly changing material.

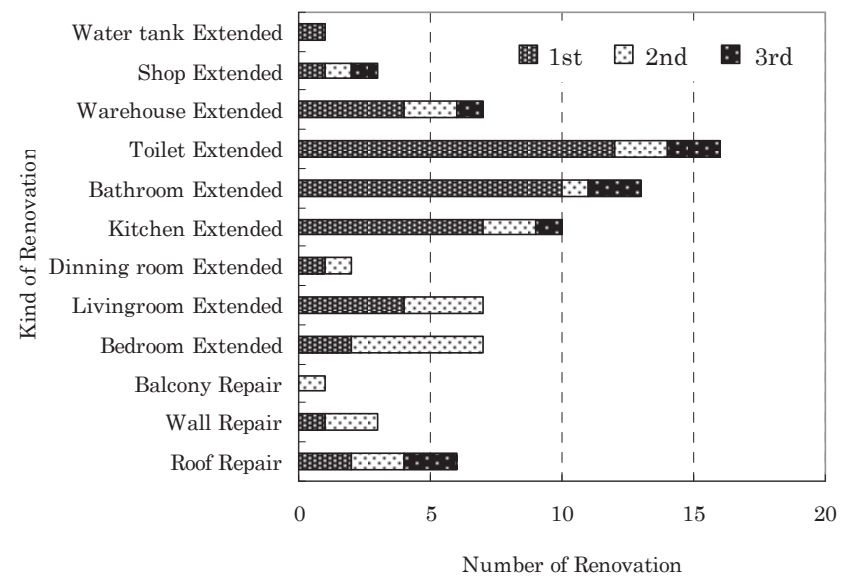

Fig.10 The contents in the step of renovation

\subsubsection{Typology of Extension}

Based on the results of the questionnaire, various positions of extension to the houses are shown in Table 1. At first we found three typical extension patterns such as: 1) creating some rooms in the underneath to be used as an open space, 2) extending some rooms on the second floor, and 3) building a detached room. By these typical patterns, 6 types of extension were classified as shown in Table 5, as follows:

Type I: This type is to use the space underneath and extended from the main house on the ground floor (House numbers 7, 11, 13 , and 17).

Type II: This type is to use the connected part of the main house on the ground floor, while the space underneath has not been used (House numbers 1 and 15).

Type III: This type is to use the space underneath enclosed all around the stilts of the main house (House numbers 12, 19, and 23).

Type IV: This type is to use a part of the underneath of the main house (House numbers 9, 10, 15, 18, 22, and 32).

Type V: This type is to use the space of extension part on the second floor that is connected to the main house (House numbers 6 and 25).

Type VI: This type is to build the detached room separated from the main house (House numbers 3, 4, 5, 6, 7, 8, 15, 17, 21, 25, and 26).

Fig. 11 shows the contents in each type of extension. The survey found that type I and type III have similar contents of extension, but type I included extension for shops. Furthermore, the rate for living room and kitchen in type $\mathrm{I}$ is higher than that in type III, while the bedroom in type III is higher than that in 
type I. Type II primary involved extension of the shop and warehouse. The extensions found in type IV were mostly to warehouse. In Type V, more extensions of kitchen and living room were found, while in type VI, more extensions of toilet and bathroom were found.

Table. 5 Renovation pattern
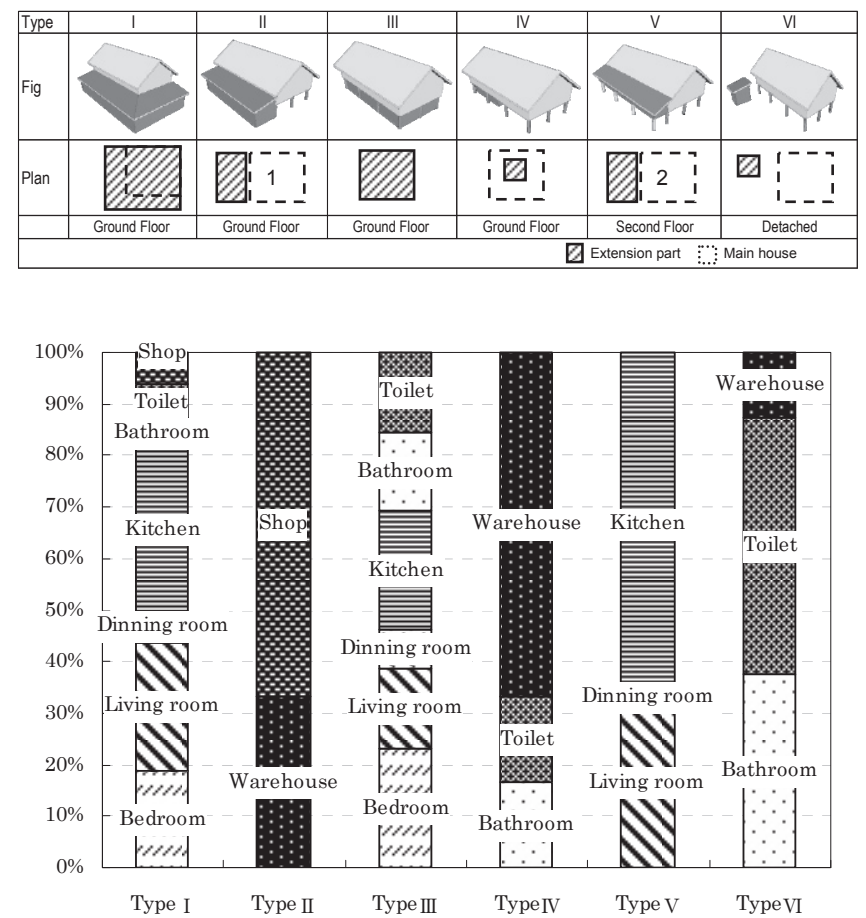

Fig. 11 The contents in each type of extension

Analysis for this study revealed that the side extended rooms in ground floor could be mainly used as shop. The enclosed rooms on the ground level all around the stilts could be mainly used as bedroom, living room, for the extended family. The partly enclosed room in underneath could be mainly used as warehouse. The extended room in the upper floor could be mainly used as kitchen or living room.

\subsection{Perception and Future prospects}

Fig. 12 shows the plans of inhabitants for future renovation of their own houses. The figure shows that the highest percentage (34\%) of answers is "to destroy and build a modern house".

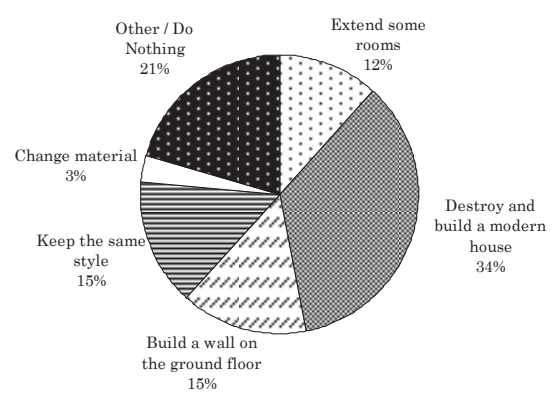

Fig. 12 Future plans for renovation of own house
The percentage of responses of "build a wall on the ground floor" and "extend some rooms" is $12 \%$ and $15 \%$, respectively. These results suggest that many people are not satisfied with their own houses. However, the proportion responding "keep the same style" is $15 \%$. This result suggests that some inhabitants still prefer the current style of Lao houses.

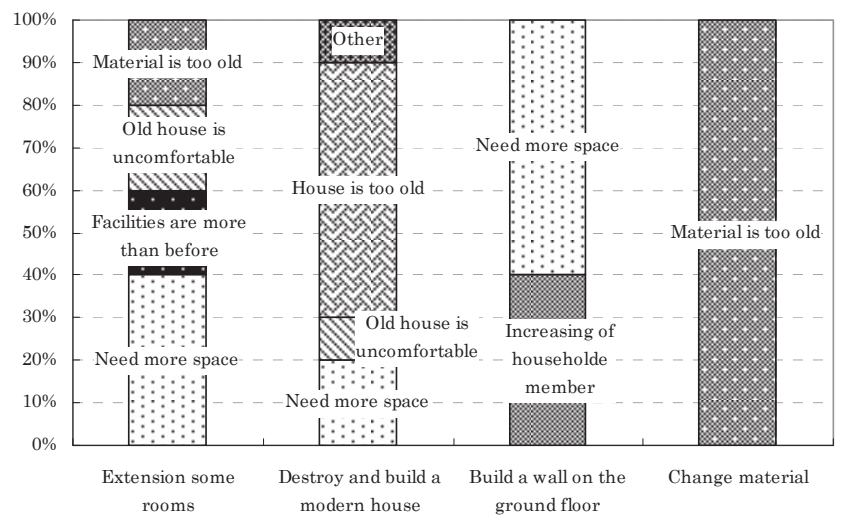

Fig. 13 Reason for planning future renovation by each future plan

The reasons motivating of inhabitants for planning future renovation by each future plan are shown in fig. 13. The reasons of inhabitants who want to "destroy and build a modern house" are almost "the house is too old". While the reason of inhabitants who want to "build a wall on the ground floor" are "they need more space", and "the increasing of their household members."

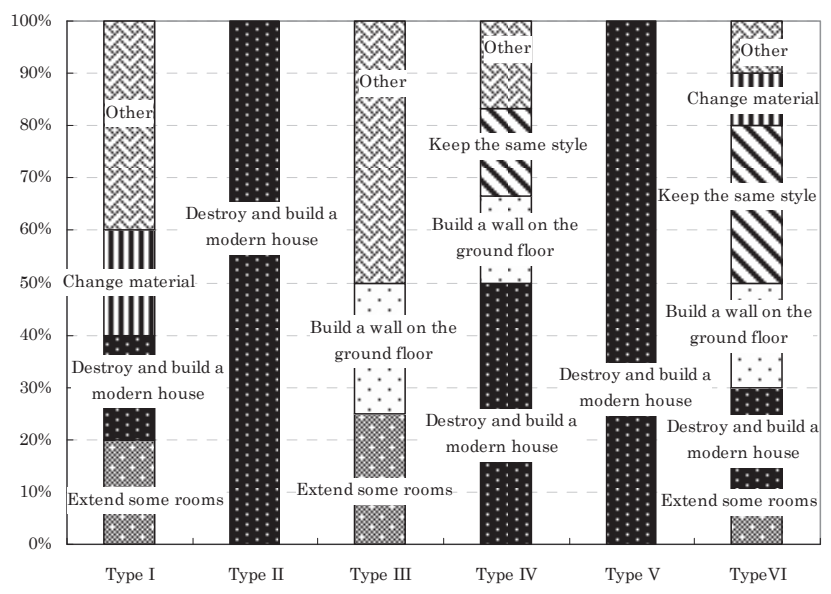

Fig. 14 The future plans for renovation in each type of extension

Fig. 14 shows the inhabitants' future plan for renovation in each type of extension. The Figure shows that most of inhabitants residing in the houses type II, and type $\mathrm{V}$ planed to "destroy and build a modern house". While almost inhabitants of house type I, and type III did not planed to "destroy and build a modern house". On the other hand the highest proportion of "keep the same style" was found among the inhabitants of house 
type IV, and type VI. These results suggest that there are few inhabitants residing in the house that build a wall on the ground floor reported to "destroy and build a modern house". These types seem to be responded to the need of recent lifestyle.

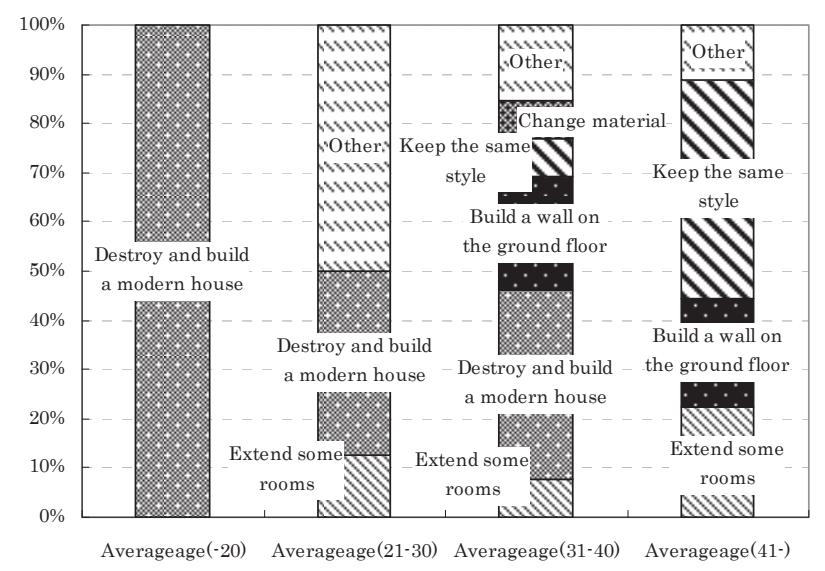

Fig. 15 Future plans for renovation in each generation

Fig. 15 shows the future plan for renovation in each generation, by 10 year age cohort. This result shows that almost all of the younger family, average age under 20 years old wants to destroy their current house and build a modern style house instead.

The middle aged family, average aged from 31 to 40 years old, reported proportions of "destroy and build modern house" and "some renovations" similarly at approximately $40 \%$. A small number wished to keep the current style of house.

Among the older family, average age 41 years old and above, the response rate of "keep the same style" reached 50\%. This result suggests that most of the young generation prefer the modern style house, while the older generations are satisfied with Lao house.

It is necessary to study how to renovate Lao house for responding to the modern lifestyle that young generation satisfies with.

\section{CONCLUSION}

This study examined the conditions and process of renovation of Lao houses in Ban-Phosi (Hatxayfong district) and Ban-Thongmang (Saythani district) both located in suburban areas of Vientiane. The findings are as follows:

1) An increasing number of renovations of Lao houses were found from 1995. This seems to be connected with the beginning of the Vientiane Integrated Urban Development Program (VIUDP) in 1994.

2) In Ban-Phosi, as an older village, number of renovation house is larger than in Ban-Thongmang. Ban-Thongmang, a newer village, where more inhabitants perform agricultural production was found more renovation of roof and extension of warehouse.
3) First step of renovation is mainly sanitary equipments, second step is mainly communicational or relaxing room extended, and the third step is mainly changing material;

4) Extensions were classified into six types. The side extended rooms in ground floor could be mainly used as shop. And the enclosed rooms on the underneath could be mainly used as living area for the extended family.

5) There are few inhabitants residing in the house that build a wall on the ground floor planed to "destroy and build a modern house". These types seem to be responded to the need of recent lifestyle.

6) Most of the younger families (under 30 years old) want to destroy and build a modern house. The middle aged families (30-40 years old), reported proportions of "destroy and build modern house" and "some renovations" similarly at approximately 40\%. Among the older families (above 40 years old), the response rate of "keep the same style" reached $50 \%$.

This paper is one of the studies that have attempted to investigate the condition and process of renovation of Lao houses. This study offers some findings regarding the contents of renovation of Lao houses in the suburban area of Vientiane that will be useful for the future design of housing in Laos. This study also serves as preliminary research on effects of the urbanization process on Lao houses. Finally, this study will form the basis for future work expanded to investigate modern houses in Vientiane that young generation will be satisfied to live in.

\section{Notes}

*1) As Grant Evans notes "one can see the rapid transformation of architecture in Vientiane and elsewhere into an extension of Thai nouveau riche styles from just across the border" (1998: 88)

*2) The typical materials (wooden, bamboo slats, hatch, etc.) were replaced by more long-lived materials (brick, steel, cement, zinc, etc.)

*3) The sample photo of a typical "Lao house" with typical characteristics

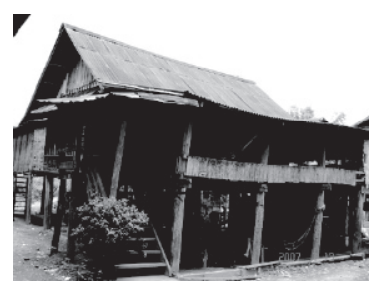
that can be found in suburban and rural areas of Lao.PDR.

* 4) Lao in $14^{\text {th }}$ century is the kingdom of Lan Xang or Lan Ch'ang (Lao:

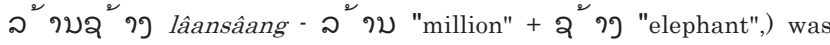
established in 1354 by Fa Ngum.

*5) Khene is the traditional Lao instrument that made from a special kind of bamboo. It looks slightly Andean in appearance with its sets of bamboo and reed pipes of various lengths, which are strapped together, and then blow into by the player.

*6) Padeck is Lao Traditional food that made with fish and salt that similar to fish sauce.

* 7) Lao is a multiethnic society with approximately 49 different ethnic groups, which are broadly lumped in terms of ethno-linguistic features into three main families: 1) Lao-Tai; 2) Mon-Khmer and Austronesian; 
and 3) Tibeto-Burmese and Hmong-Ioumien. Lao group is the majority group of Lao people. (State Planning Committee., 1997)

* 8) PHONGSAVANH, S., ABE, H. and YOSHIDA, K. (2009) "Inhabitants Consciousness Concerning Detached Houses in the City and Suburbs of Vientiane, Lao PDR - A Case Study of Students' House at the National University of Laos - ". JAAB., Vol8 No.2. pp.339-346.

* 9) There are nine districts in Vientiane such as; Chanthabouli, Sisattanak, Sikhottabong, Xaysetta, Hatxayfong, Naxaythong, Saythani, Paknguem, and Sangthong district.

* 10) That was approved at the Fourth Party Congress in November 1986, with the adoption of the "New Economic Mechanism" (NEM).

* 11) Askew, M., Logan, W. and Long, C (2007) "Transformation of Lao landscape." Routledge (London and New York), p. 195.

\section{References}

1) CHAZEE, L. (1999) "The people of Laos, Rural and Ethnic diversities." Bangkok, White Lotus Press, p. 39

2) CHIRANTHANUT, C. and FUNO, S. (2008) "Considerations on Spatial formation and transformation of Kaloeng house in Mukdahan Province, Thailand" Journal of Architecture and Planning., AIJ, Vol. 73 No. 633, pp. 2285-2292, 2008. 11

3) CLEMENT, S. and CLEMENT, P. (1990) "L'habitation Lao dans les régions de Vientiane et de Luang Prabang” (préface de Lucien Bernot), Paris, Peeters, 2 vol.,

4) CONNORS, M. (1996) "Lao Textiles and Traditions". Oxford University Press, p. 23

5) DENPAiBOON, C., TOHIGUCHI, M., MATSUDA, H. and HASHIMOTO, S. (2000) "Typology and Life-Style analysis of the Raft house (Ruan Pae) in Riverine settlements in Thailand.” Journal of Architecture and Planning., AIJ, No. 533, pp. 173-180, 2000. 7

6) EVANS, G. (1998) "The Politics of Ritual and Remembrance: Laos since 1975”. Silkworm, Chiang Mai, p. 88

7) KOMOTO, J., SITTHIVAN, S. and YOSHIDA, K. (2004) "Modal Characteristics on Housing at the Rural Area in the Middle Region, LAO PDR." Journal of Architecture and Planning., AIJ, No.577, pp. 89-96, 2004. 3

8) LNSC (Lao National Statistic Center), Vientiane Population Census of 2005.

9) LEBAR, F. and SUDDARD, A. (1967) "Laos" its people, its society, its culture, New Haven: HRAF, p. 13

10) LOGAN, W., LONG, C. and HANSEN, R. (2002) "The Disappearing Asian City." Protecting Asia's Urban Heritage in a Globalizing world, Oxford University Press, pp. 51-69

11) SAYARATH, C. (2003) "Vientiane Civil and Religious Architecture". Droit reserve a l'Atelier du Patrimoine a Vientiane, pp. 31-33

12）福山愛, 他 4 名: カドゥー族の住宅空間と住まい方についてー南ラオ ス・タンゴー村，ピンベー村のロングハウスに関する考察（その 2) - , 日本建築学会大会学術講演梗概集 E-2 分冊, pp 575-576, 2005.9

13）平田智隆，他 3 名：集落に見る空間的特性と変容に関する研究一北ラオ ス・アカ族の事例を通して（その 1) - , 日本建築学会大会学術講演梗概 集 E-2 分冊, pp 163-164, 2006.9

14）宮澤宏和, 他 1 名：タリアン族における住居・集落の構成原理に関する 考察, 一ラオス山地民の居住形態に関する研究 (その 3) - , 日本建築学 会大会学術講演梗概集 E-2 分冊, pp 77-78, 2004.8

15）東嶌孝明，他 5 名：通過的居住地における住居集合に関寸る研究，一ラ オス・都市近郊におけるモンの事例（その 2）－，日本建築学会大会学術 講演梗概集 E-1 分冊, pp 81-82，2007.8

\section{和文要約}

本研究はラオス・ヴィエンチャンの周辺村落におけるラオ八ウスの 住宅改善の状況と住民の認識を明らかにすることを目的する。これ は都市化の進むヴィエンチャンにおいて今後の住宅供給を考えるた めの手がかりとするためである。ここではヴィエンチャン郊外にあ る二つの村（ポウシ村、トマン村）におけるラオ八ウスのフィール ド調査と住民へのアンケート調査を行ない、以下の結果を得た。1） ラオ八ウスの住宅改善が増加している時期は 1995 年からである。 2)古くからあるポウシ村は比較的新しいトマン村に比べて住宅改善 の件数が多い。また主として農業で生活をしているトマン村では倉 庫や屋根の改修が多い。3） 1 度目の住宅改善で多いのは主に衛生 設備で、2 度目の住宅改善は主に生活の場所、3 度目は材料の更新 が多い。4）増築パターンは 6 タイプある。一階部分を横に増築す る場合は店鋪などが多く、ピロティを壁で囲む場合は親族の居間や 寝室などが多い。5）一階のピロティを増築した住民はラオ八ウスの 将来の建て替えを計画していない。6)若い家族（30 歳未満）の多く はラオ八ウスを建て替えたいと考えている。また中年齢の家族（30 歳〜40 歳) はラオ八ウスを建て替えたいと言う意見と住宅改善をし て住むと言う意見が約 $40 \%$ で同じであり、高年齢の家族（40 歳以 上）は現在のスタイルを維持したいと言う意見が $50 \%$ に達している。 今後は以上の結果を手かがりにして、さらにデータを増やすととも に、ヴィエンチャンの都心部分における新しい住宅地におけるラオ ハウスの調查を行い、若い世代にも対応できるラオ八ウスの住宅改 善の方法を検討したい。

（2009年12月10日原稿受理，2010年 4 月30日採用決定） 